\title{
Scrippsiella irregularis sp. nov. (Dinophyceae), a new dinoflagellate from the southeast coast of Iran
}

\author{
Gilan Attaran-Fariman* and Christopher J.S. Bolch \\ School of Aquaculture, University of Tasmania, Locked Bag 1370, Launceston, Tasmania 7250, Australia
}

\begin{abstract}
G. Attaran-Fariman and C.J.S. Bolch. 2007. Scrippsiella irregularis sp. nov. (Dinophyceae), a new dinoflagellate from the southeast coast of Iran. Phycologia 46: 572-582. DOI: 10.2216/07-02.1

A new species of Scrippsiella is described by light and electron microscopy from laboratory cultures established from
resting cysts collected from the southeast coast of Iran. Comparative morphological analyses and sequencing of the
rDNA-ITS and $5.8 S$ rDNA show that the new species, Scrippsiella irregularis sp. nov, is allied to but distinct from
Scrippsiella precaria and $S$. ramonit. Vegetative cells of the new species are similar in size, shape, and plate tabulation to
$S$. precaria; however, the cingulum is equatorially placed, the nucleus is in the hypocone, and the second anterior
intercalary plate is larger and rounded rather than diamond-shaped. The resting cysts isolated from sediments and
produced in laboratory cultures are spherical to ovoid with numerous pointed to slightly capitate calcareous processes.

KEY Words: Scrippsiella, Resting cyst, DNA, Phylogeny, rDNA-ITS, Iran, Oman Sea
\end{abstract}

\section{INTRODUCTION}

Phytoplankton cells of the photosynthetic dinoflagellate genus Scrippsiella Balech \& Loeblich III species are relatively small $(15-40 \mu \mathrm{m})$ thecate, autotrophic cells that generally produce calcareous resting cysts. A few species produce organic-walled cysts, such as Scrippsiella hangoei Schiller (Larsen et al. 1995) and Scrippsiella imariense Kobayashi \& Matsuoka (Kobayashi \& Matsuoka 1995).

Phytoplankton cells and resting cysts of Scrippsiella species are regular and dominant components of the dinoflagellate flora of coastal marine waters and sediments around the globe (Honsell \& Cabrini 1991; Faust 1996; Godhe et al. 2000; Montresor et al. 2003). In tropical and subtropical regions, the diversity and abundance of Scrippsiella resting cysts appears to be as high or higher than that of temperate regions (Dale 1992; Vink 2004), yet our knowledge of the diversity of the genus from the tropical phytoplankton is very limited.

During a study of dinoflagellate cysts from tropical southeast coast of Iran, we found several Scrippsiella-like calcareous cyst types that could be germinated to produce a range of morphologically distinct Scrippsiella cells. Some morphotypes established from these germinations exhibited asymmetrically arranged intercalary plates. In this paper we compare the cyst and cell morphology and nucleotide sequence of the rDNA-ITS and 5.8S-rDNA of these cells with those of related species and describe a new species, Scrippsiella irregularis sp. nov., from laboratory cultured material.

\section{MATERIAL AND METHODS}

\section{Sediment collection and processing}

Sediment samples were collected by an Ekman grab from three locations: the Bahoo-Kalat estuary, the coastal area

*Corresponding author (gilanattaran@ifro.ir). near Pasabandar, and Chabahar Bay on the southeast coast of Iran (Fig. 1). The surface sediment from the grab samples was bottled and transported in the dark at $20^{\circ} \mathrm{C}$ until it was processed in the laboratory. Approximately 2 $4 \mathrm{~g}$ of wet sediment were mixed with $0.2-\mu \mathrm{m}$ filtered seawater in an $80-\mathrm{ml}$ plastic container to obtain a watery slurry and sonicated for 2 min using a Microson ultrasonic cell disruptor (small probe, $200 \mathrm{~W}$ ) to separate detrital particles from resting cysts. Samples were filtered through a $125-\mu \mathrm{m}$ sieve, collected on a $20-\mu \mathrm{m}$ sieve (Bolch \& Hallegraeff 1990), and resuspended in distilled water. Live resting cysts were then concentrated using a two-step density gradient centrifugation consisting of an upper layer composed of distilled water $\left(1.0 \mathrm{~g} \mathrm{~cm}^{-3}\right)$ and a lower layer of sodium polytungstate $\left(1.3 \mathrm{~g} \mathrm{~cm}^{-3}\right)$ (Bolch 1997).

\section{Cyst germination and culture experiments}

Individual cysts were isolated from processed and washed sediment suspensions using a flame-drawn micropipette and a Leica stereomicroscope. Cysts were washed twice in sterile GSe growth medium (GSe medium, 35-ppt salinity; Blackburn et al. 1989), placed individually in 55-mm polystyrene Petri dishes containing $10 \mathrm{ml}$ of GSe medium which were then sealed with Para-film and incubated at $27 \pm 0.5^{\circ} \mathrm{C}$ under cool-white fluorescent light $(70-90 \mu \mathrm{mol}$ photons PAR $\mathrm{m}^{-2} \mathrm{~s}^{-1}$ ) with a 12-h light: 12 -h dark cycle. After germination, cells were allowed to divide and grow to a cell concentration sufficient for transfer to 100-ml Erlenmeyer flasks containing $50 \mathrm{ml}$ of growth medium. Resultant clones were subcultured every 4 weeks. Separate subcultures were also acclimatised to lower temperatures by transfer to $23^{\circ} \mathrm{C}$ for at least one transfer cycle ( 3 weeks) followed by transfer to $17^{\circ} \mathrm{C}$ for long-term culture maintenance.

For encystment studies, $S$. irregularis strains $\mathrm{SCBC} 17$ and $\mathrm{SCBC} 19$ maintained at $27^{\circ} \mathrm{C}$ were each inoculated into polystyrene Petri dishes containing $20 \mathrm{ml}$ of nitrate- and phosphate-deficient GSe medium and incubated under the conditions described above. Dishes were examined regular- 

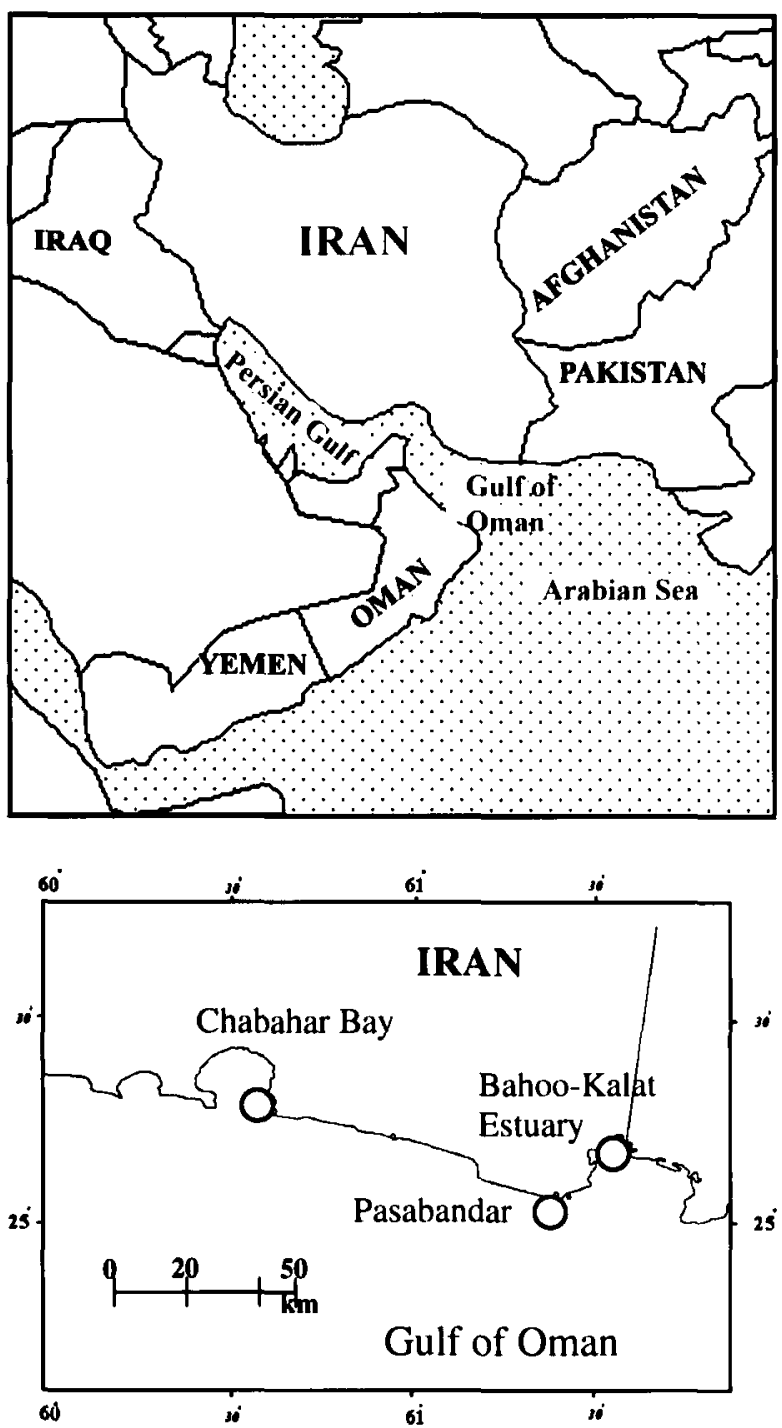

Fig. 1. Map of the study area showing sites from which triplicate surface sediment samples were collected.

ly for the presence of calcareous resting cysts, which were then examined using light and scanning electron microscopy (SEM).

\section{Microscopy}

Cultured and wild resting cysts of $S$. irregularis were photographed with an Olympus $\mathrm{BH}-2$ light microscope equipped with a Leica DC300F digital imaging system. The plates of germinated thecate cells were stained with Calcofluor M2R (Fritz \& Treimer 1985) and examined by fluorescent microscopy using a broadband UV filter (Olympus filter set no. 488). For SEM, cells in a $10-\mathrm{ml}$ aliquot of culture were concentrated by centrifugation $(5 \mathrm{~min}$ at $1000 \times \mathrm{g}$ ), collected on poly-lysine-coated coverslips (Marchant \& Thomas 1983) and dehydrated in a graded methanol series $(10-100 \%$ in eight steps). Mounted specimens were then dried from hexamethyldisilazane (Nation 1983) and placed on SEM stubs for examination by SEM. Individual cysts were also isolated from processed sediments, washed twice in distilled water, placed on $1-\mu \mathrm{m}$ Nucleopore filters, and air-dried before mounting the filters on SEM stubs. All stubs were sputtercoated with gold and examined with a Philips Quanta 600 or JEOL JSM-840 scanning electron microscope.

\section{DNA extraction and sequencing}

Approximately $10 \mathrm{ml}$ of exponential growth-phase cultures SCBC17, SCBC19 were pelleted by gentle centrifugation $(1500 \times \mathrm{g}$ for $5 \mathrm{~min})$ and the supernatant discarded. DNA was extracted using a phenol/chloroform, gentle-lysis method described by Bolch et al. (1998). The extracted DNA was precipitated by the addition of one-tenth volume of $3 \mathrm{M}$ sodium acetate and two volumes of cold ethanol, and the DNA pelleted recovered by centrifugation for $20 \mathrm{~min}$ at $14,000 \times \mathrm{g}$. Cell pellets were washed twice in $70 \%$ ethanol, air-dried, and resuspended in sterile Milli-Q water or TE buffer. DNA quality was verified by $1 \%$ agarose gel electrophoresis, and subsamples were diluted to an approximate concentration of $10 \mathrm{ng} \mu^{-1}$ and used as templates for PCR. The internal transcribed spacer and 5.8S rRNA gene (rDNA-ITS) region was amplified using the primers ITSA [5'-CCA AGC TTC TAG ATC GTA ACA AGG (ACT) TCC GTA GGT-3'] and ITSB [5-CCT GCA GTC GAC A(TG) ATG CTT AA(AG) TTC AGC (AG)GG-3'] (Adachi et al. 1994).

PCR reactions were performed in 50- $\mu$ l volumes in thinwalled 200- $\mu$ l PCR tubes. The PCR reactions contained Bioline $\mathrm{NH}_{4}$ PCR reaction buffer [ $160 \mathrm{mM}\left(\mathrm{NH}_{4}\right)_{2} \mathrm{SO}_{4}, 670 \mathrm{mM}$ Tris$\mathrm{HCL}$, and $0.1 \%$ Tween-20], $3 \mathrm{mM} \mathrm{MgCl}_{2}, 200 \mu \mathrm{M}$ dNTPs, $10 \mathrm{pM}$ of each primer, $1 \mathrm{U}$ BioTaq DNA polymerase (Bioline, UK), and $10 \mathrm{ng}$ of template DNA. Thermocycling was as follows: initial denaturation of $2 \mathrm{~min}$ at $94^{\circ} \mathrm{C}$, followed by 35 cycles of $94^{\circ} \mathrm{C}$ for $1 \mathrm{~min}$, annealing at $60^{\circ} \mathrm{C}$ for $1 \mathrm{~min}$, elongation at $72^{\circ} \mathrm{C}$ for $2 \mathrm{~min}$, and a final extension of $6 \mathrm{~min}$ at $72^{\circ} \mathrm{C}$. The PCR products were stored at $-20^{\circ} \mathrm{C}$ until further analysis. The presence of the specific amplification products were verified using agarose gel electrophoresis. Successful PCR products were purified using Montage ${ }^{\text {TM }}$ PCR Devices (Millipore, Billerica, MA, USA) according to the manufacturer's protocols, and DNA was quantified using a Turner TBS-380 DNA fluorometer. Purified PCR products were sequenced in both directions with the forward or the reverse primer using a Dye Terminator Sequencing Kit (BeckmanCoulter, Fullerton, CA, USA) following the manufacturer's protocols and completed reactions electrophoresed on a Beckman-Coulter CEQ2000 capillary sequencer.

\section{Alignment and phylogenetic analyses}

Nucleotide sequences were checked by manual inspection of electropherograms in both directions and base-calling errors corrected manually using the software program BioEdit (Hall 1999). Sequences obtained from the present study and related dinoflagellate sequences available from GenBank were aligned using ClustalX version 1.83 (Jeanmougin et al. 1998) and improved by manual inspection. PAUP* $4.0 \mathrm{~b} 10$ for Macintosh (Swofford 2002) was used for phylogenetic analyses. Initial neighbourjoining analyses included 56 rDNA-ITS sequences from Calciodinellaceaean dinoflagellates (Table 1) to establish 
Table 1. Details of the 56 strains and GenBank accession numbers of DNA sequences used in preliminary analyses. The 27 DNA sequences used in the final phylogenetic analyses are indicated $(+)$. Sequences generated during this study indicated in bold text.

\begin{tabular}{|c|c|c|c|}
\hline Taxon & Strain no. & GenBank no. & Reduced data set \\
\hline Calciodinellum albatrosianum & GeoB 149 & AY676143 & \\
\hline Calciodinellum albatrosianum & M34-*26/4 & AY 676145 & + \\
\hline Calciodinellum albatrosianum & M34-17 & AY676144 & \\
\hline Calciodinellum levantinum & GeoB 122 & AY 676146 & + \\
\hline Calciodinellum levantinum & GeoB*165 & AY 676147 & \\
\hline Calciodinellum operosum & CalopeD006 & AY327462 & + \\
\hline Calciodinellum sp. & GeoB 120 & AY676148 & + \\
\hline Ensiculifera aff. imariensis & D207 & AY728076 & + \\
\hline Ensiculifera cf. imariensis & JB3 & AF527814 & + \\
\hline Ensiculifera loeblichi & UTEXLB1595 & AF527815 & + \\
\hline Heterocapsa pygmaea & CCMP1322 & AB084093 & + \\
\hline Heterocapsa triquetra & NIES 7 & AB084101 & + \\
\hline Pentapharsodinium dalei & SZN19 & AF527817 & + \\
\hline Peridinium cinctum & CCAC 0102 & AY499511 & + \\
\hline Pernambugia tuberosa & GeoB 61 & AY499519 & + \\
\hline Scrippsiella hangoei & SHTV1 & AY499515 & + \\
\hline Scrippsiella infula & GeoB 110 & AY499523 & + \\
\hline Scrippsiella irregularis & SCBC17 & EF584460 & + \\
\hline Scrippsiella irregularis & SCBC19 & EF584461 & + \\
\hline Scrippsiella lachrymosa & D192 & AY728078 & + \\
\hline Scrippsiella lachrymosa & $1025-01$ & AY676150 & \\
\hline Scrippsiella precaria & CS-294 & AY499518 & + \\
\hline Scrippsiella ramonii & SZN7 & AF 527820 & + \\
\hline Scrippsiella rotunda & SZN66 & AF527821 & + \\
\hline Scrippsiella sp. & CS-168 & AY 499533 & \\
\hline Scrippsiella sp. & D1006 & AY728079 & \\
\hline Scrippsiella sp. & GeoB 138 & AY499525 & \\
\hline Scrippsiella sp. & GeoB 188 & AY499524 & \\
\hline Scrippsiella sp. & $\mathrm{GeoB}^{*} 160$ & AY499526 & \\
\hline Scrippsiella sp. & GeoB*161 & AY499527 & \\
\hline Scrippsiella sp. & $\mathrm{M} 34-* 25 / 5$ & AY499531 & + \\
\hline Scrippsiella sp. & SCBC21 & EF584453 & \\
\hline Scrippsiella sp. & SCBC116 & EF584459 & \\
\hline Scrippsiella sweeneyae & NIES 684 & AY499520 & + \\
\hline Scrippsiella trifida & GeoB 109 & AY499521 & + \\
\hline Scrippsiella trochoidea & D201 & AY 728080 & \\
\hline Scrippsiella trochoidea & $\mathrm{GeoB} * 200$ & AY 676157 & \\
\hline Scrippsiella trochoidea & $\mathrm{GeoB}^{*} 201$ & AY 676158 & \\
\hline Scrippsiella trochoidea & $\mathrm{GeoB} * 214$ & AY 676160 & \\
\hline Scrippsiella trochoidea & IO $14-01$ & AY 676162 & \\
\hline Scrippsiella trochoidea & IO 26-01 & AY 676163 & \\
\hline Scrippsiella trochoidea & NIES 369 & AY499530 & + \\
\hline Scrippsiella trochoidea & SZN33 & AF 527070 & \\
\hline Scrippsiella trochoidea & SZN61 & AF527075 & \\
\hline Scrippsiella trochoidea & SZN64 & AF527079 & \\
\hline Scrippsiella trochoidea & SZN82 clone 49 & AF527101 & + \\
\hline Scrippsiella trochoidea & SCPC18 & EF584454 & \\
\hline Scrippsiella trochoidea & SCPC36 & EF584455 & \\
\hline Scrippsiella trochoidea & SCPC39 & EF584458 & \\
\hline Scrippsiella trochoidea & SCPC51 & EF584457 & \\
\hline Scrippsiella trochoidea & SCPC73 & EF584456 & \\
\hline Scrippsiella trochoidea var. aciculifera & GeoB 228 & AY499529 & + \\
\hline Scrippsiella trochoidea var. aciculifera & $\mathrm{GeoB} * 213$ & AY676164 & \\
\hline Scrippsiella trochoidea var, aciculifera & SCCAP499 & AF527066 & \\
\hline Scrippsiella trochoidea var, aciculifera & SZN60 & AF527071 & \\
\hline Scrippsiella trochoidea var. aciculifera & SZN63 clone 135 & AF527078 & + \\
\hline
\end{tabular}

the major branching patterns and clusters among the taxa. However, the analytical time required for maximum likelihood and parsimony analyses with this large data set was unworkable; therefore the data set was reduced to 27 taxa by excluding identical sequences and reducing each terminal cluster to one or two representatives. The final alignment contained 757 characters (including gaps introduced for alignment purposes). The peridinioid taxa Heterocapsa pygmaea A.R. Loeblich, Heterocapsa triquetra Ehrenberg
(Stein), and Peridinium cinctum Muller were used as outgroups to root the analyses.

Significant phylogenetic structure in the data set was estimated by the random tree method and probability tables using the critical values of $g_{1}$ (Hillis \& Huelsenbeck 1992). Phylogenetic trees were constructed using neighbour-joining (NJ) and maximum parsimony (MP). NJ analyses used the mean distance and $\log$ Det-Paralinear distance matrices. Most parsimonious trees were found using the branch and 

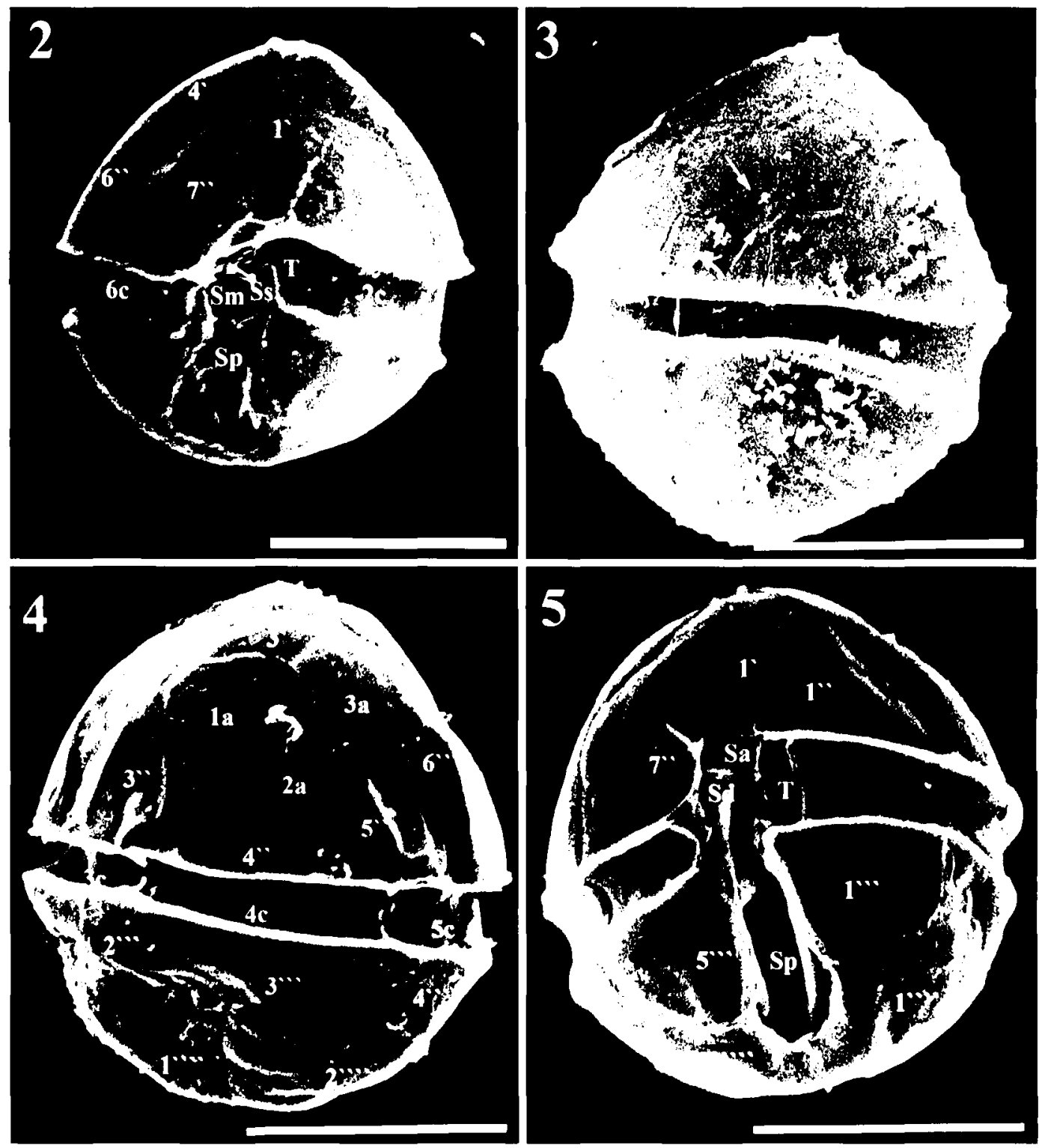

Figs 2-5. SEM. Vegetative cell of Scrippsiella irregularis (Fig. 2-1C19; Fig. 3-1C17; Figs 4, 5-2C19). All scale bars = $10 \mu \mathrm{m}$.

Fig. 2. Ventral view showing the plate pattern.

Fig. 3. Dorsal view showing the second intercalary plate (arrows) and slight narrowing of the cingulum on the dorsal side of the cell.

Fig. 4. Dorsal view of cell showing the plate pattern and rounded shape and size of 2 a plate.

Fig. 5. Ventral view showing sulcal and postcingular (1"', $\left.5^{\prime \prime \prime}\right)$ plates. Note the $S_{m}$ plate almost hidden by wing of $S_{d}$ plate.

bound algorithm. All characters were equally weighted, and gaps were treated as missing data, with multistate characters (DNA ambiguities) interpreted as uncertainty. Bootstrap analyses of NJ and MP trees (Felsenstein 1985) utilised 200 replicates of the heuristic search algorithm.

\section{RESULTS}

\section{Description and observations}

\section{S. irregularis Attaran-Fariman \& Bolch sp. nov.}

Figs 2-19

Cellulae ovoideae, leviter dorsiventraliter compressae, 17-29 $\mu \mathrm{m}$ longae, 13-23 $\mu \mathrm{m}$ latae. Epitheca rotundata, conica lateribus convexis, sine cornu apicali; hypotheca rotundata. Cingulum subaequatoriale descendens, per dimidiam partem vel per totum latitudinis suae dislocatum. Formula laminarum Po, X, 4' 3a, 7", $6 \mathrm{C}(5 \mathrm{C}+1), 6 \mathrm{~S}, 5^{\prime \prime \prime}, 2^{\prime \prime \prime \prime}$. Laminae $1 \mathrm{a}$ et $3 \mathrm{a}$ adjacentes, hexagonae et forma similes. Lamina $2 a$ infra et inter laminas la et $3 a$, subrectangularis vel rotundata. Sulcus valde distinctus, antapicem non attingens. Lamina anterior sulcalis (Sa) latior quam longior, super porum flagellarum et laminas sulcales extensa. Nucleus magnus sphaericus, in hypotheca. Chloroplasti aliquot, globulares, peripherales, fuscovirides. Cystae quiescentes sphaericae vel ovoideae, $20-26 \mu \mathrm{m}$ in diametro, spinis multis calcareis acicularibus vel capitatis $3.5-4.5 \mu \mathrm{m}$ longis.

Cells ovoid in outline, slightly dorsoventrally compressed, 17$29 \mu \mathrm{m}$ long, 13-23 $\mu \mathrm{m}$ wide. Epitheca rounded, conical with convex sides and no apical horn; hypotheca rounded. Cingulum subequatorial and descending, displaced one-half to one 


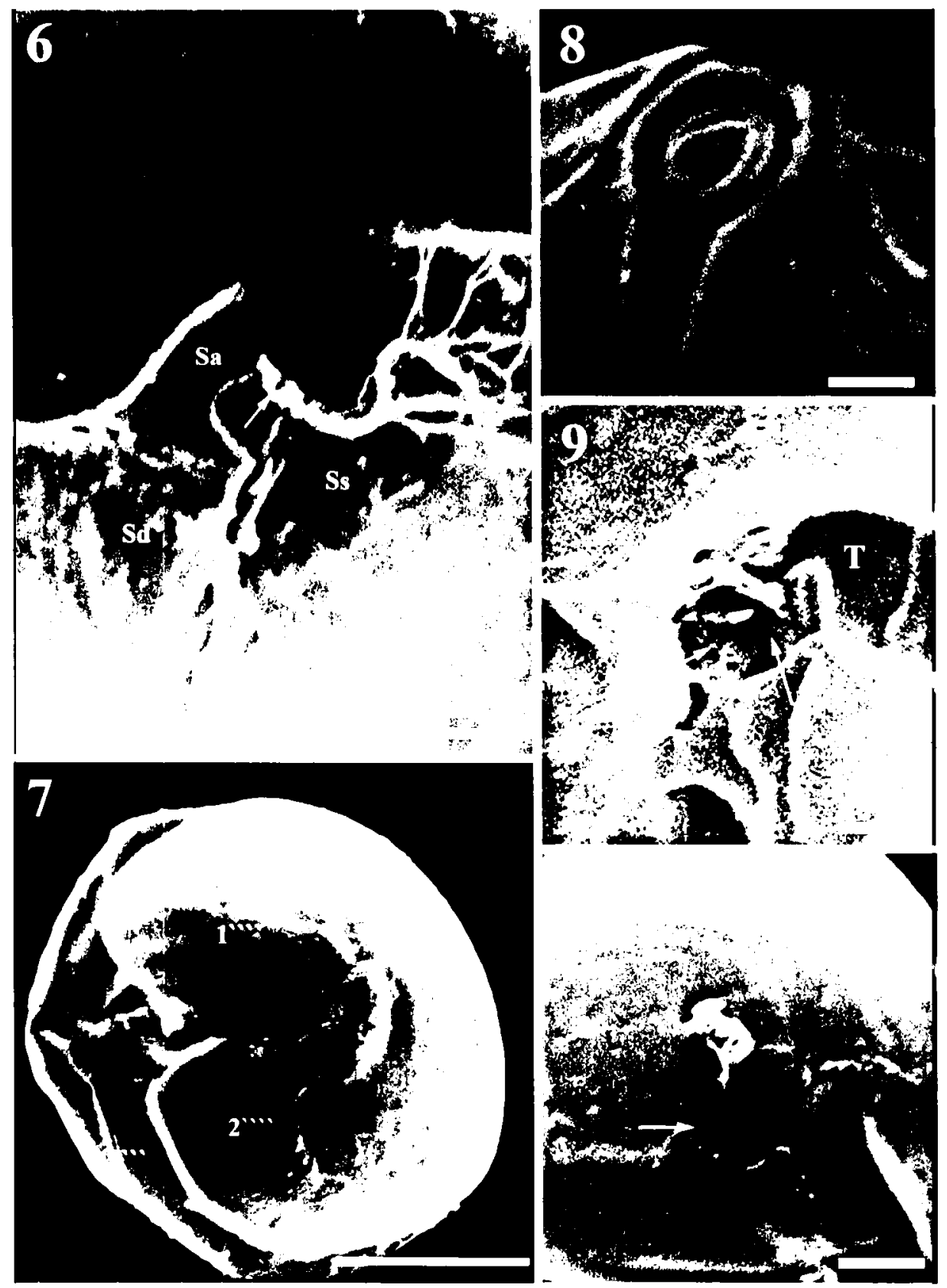

Figs 6-10. SEM. Vegetative cell of Scrippsiella irregularis (Fig. 6-1C17; Fig. 7-1C19; Fig. 8-2C17; Fig. 9-1C17: Fig. 10-2C19). All scale bars $=2 \mu \mathrm{m}$, except Fig. $6=10 \mu \mathrm{m}$.

Fig. 6. Sulcal area showing the transverse and longitudinal flagella. Note the shape of $S_{a}$ and $S_{d}$ plates.

Fig. 7. Antapical view of cell.

Fig. 8. Apical view showing apical pore and canal plates.

Fig. 9. Sulcal plates, showing the shape of $S_{\mathfrak{m}}$ (left arrow) and $S_{s}$ plates (right arrow) and the transitional plate.

Fig. 10. Dorsal view, showing intercalary plates, note 2 a plate (arrow).

cingulum width, narrowing dorsally. Plate formula Po, $X, 4^{\prime} 3 a$, $7^{\prime \prime}, 6 \mathrm{C}(5 \mathrm{C}+1), 6 \mathrm{~S}, 5^{\prime \prime \prime}, 2^{\prime \prime \prime \prime}$. Plate la and 3a adjacent, hexagonal and similar in shape. Plate $2 a$ below and between plates $l a$ and $3 a$, subrectangular to rounded in shape. Sulcus well defined, not extending to the antapex. Anterior sulcal plate $\left(S_{i a}\right)$ broader than long, extending over flagella pore and sulcal plates. Nucleus large, spherical and positioned in the hypotheca. Cells contain several globular, peripherally placed, dark brown-green chloroplasts. Resting cysts spherical to ovoid, $20-26 \mu \mathrm{m}$ diameter, with numerous nontabular calcareous acicular or capitate spines of $3.5-4.5 \mu \mathrm{m}$ in length.
HOLOTYPE: Figure 2; Strain SCBC17; established from an individual resting cyst germinated and cultured from coastal sediments collected from Bahoo-Kalat estuary, southeast coast of Iran, March 2004. Cultures are maintained at the University of Tasmania, School of Aquaculture, Algae Culture Unit, Launceston, Australia.

TYPE LOCALITY: Bahoo-Kalat Estuary, Iran.

ETYMOLOGY: 'irregularis' - in which symmetry is destroyed by some inequality of parts; referring to the lack of symmetry of the anterior intercalary plates. 

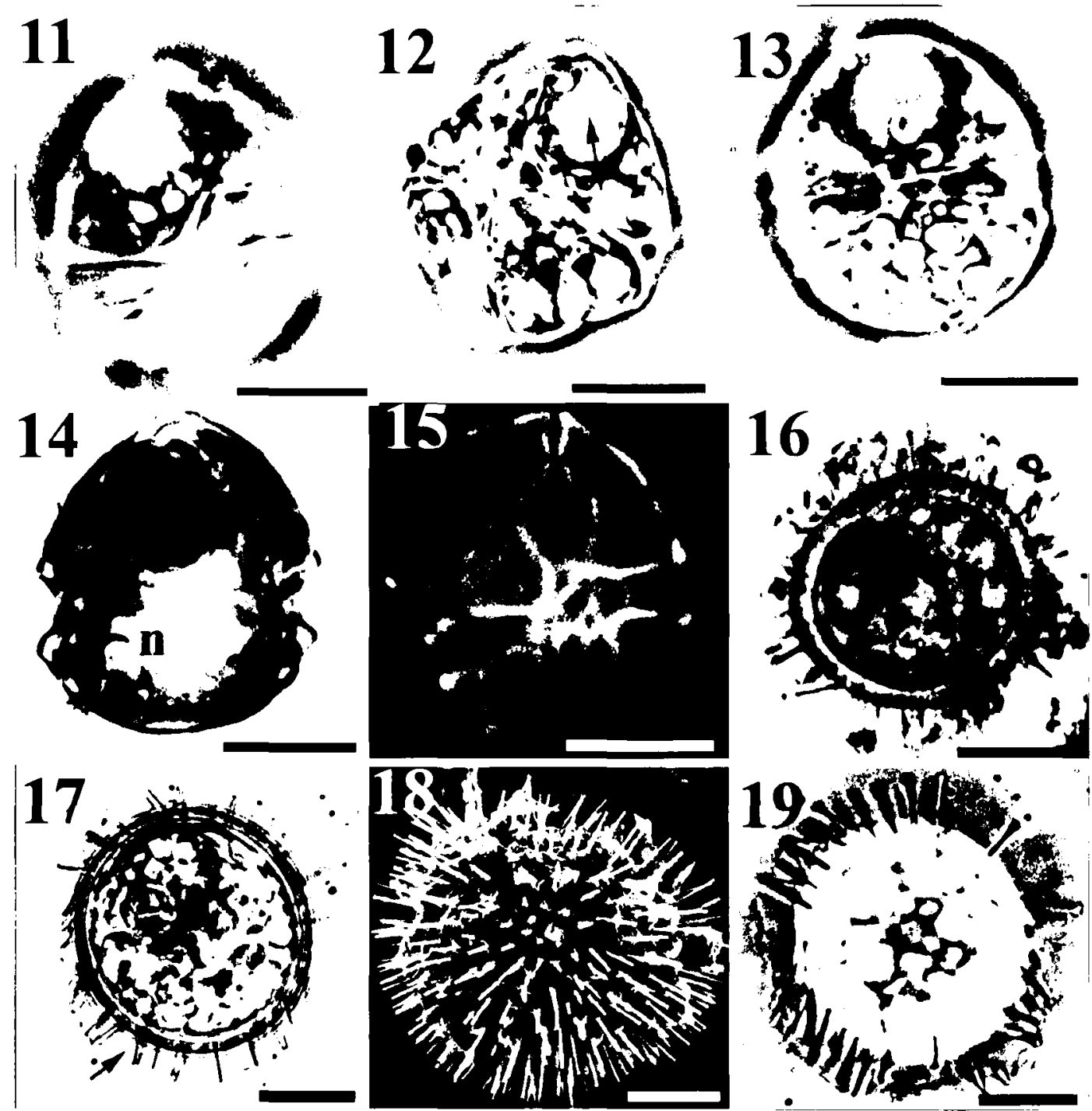

Figs 11-19. Light microscopy. Vegetative cells and cysts of Scrippsiella irregularis. All scale bars $=10 \mu \mathrm{m}$.

Fig. 11. Ventral view of cell showing cingulum displacement.

Fig. 12. Ventrolateral view. Arrow showing large accumulation body.

Fig. 13. Dorsal view showing the cingulum narrowing on dorsal side (arrow)

Fig. 14. Dorsal view of cell showing the large nucleus $(n)$ in the hypotheca. Note irregular arrangement and shape of the chloroplasts (arrow).

Fig. 15. Calcofluor-stained cell showing the ventral plate patterns.

Fig. 16. Light microscopy. Resting cyst isolated from sediment.

Fig. 17. Light microscopy. Cultured resting cyst showing cell content and accumulation body. Note the transparent membrane surrounding the spines (arrow).

Fig. 18. SEM. Wild eyst showing the calcareous spines.

Fig. 19. Light microscopy. Cultured cyst with surface focus showing the spines.

DISTRIBUTION: Southern coast of Iran. Bahoo-Kalat Estuary.

REMARKS: The vegetative cells of cultures $\mathrm{SCBC} 17$ and SCBC 19 are ovoid and slightly dorsoventrally compressed and possess a rounded epitheca with convex sides. The apex is rounded with no pronounced apical horn (Figs $2-5$ ). The hypotheca is semicircular in outline. The cells are 17-29 $\mu \mathrm{m}$ ( $\bar{X}=22 \mu \mathrm{m}, n=50)$ in length and $13-23 \mu \mathrm{m}(\bar{X}=18 \mu \mathrm{m}, n$ $=50$ ) in width. The epitheca is longer than the hypotheca (length : width ratio $=1.4$ ). The cingulum is left-handed and displaced one-half to one cingulum width (Figs 2, 5.
11). The cingular width varies from 2.6 to $3.6 \mu \mathrm{m}(\bar{X}=$ $2.9 \mu \mathrm{m}, n=20$ ). The border between the cingulum and hypotheca is curved, and the cingulum narrows slightly on the dorsal side (Figs 3, 13). The dorsal narrowing can be observed in both fixed and live cells by light microscopy and SEM; however, this may be accentuated by slight cell compression under a coverslip or cell swelling during SEM fixation. The plate formula is the same as other Scrippsiella species [i.e. Po, X, 4', 3a, 7", 6C (5C+1 transitional plate $=$ T-plate), 5S, 5"', 2"'"; see Figs 2, 4, 5, 7], but the shape, position, and relationship between the three anterior 
intercalary plates is atypical. The plates are located diagonally on the dorsal part of the epicone (Figs 3, 4); plates $1 a$ and $3 a$ are six-sided and in contact on their anterior margins (Fig. 4). Plate $2 a$ is subrectangular with two convex sides and is positioned between the posterior margins of plates $1 \mathrm{a}$ and $3 \mathrm{a}$ (Figs $3,4,10$ ).

The sulcus is composed of five plates: $S_{a}, S_{p}, S_{s}, S_{d}$, and $S_{m}$ plates (Figs 2, 5). $S_{a}$ is located between $1^{\prime}$ and $7^{\prime \prime}$ and exhibits a hook-like extension over the flagellar pore, the sulcal plates, and the border with the T-plate (Figs 5, 15). The $S_{p}$ plate contacts the $T$-plate and extends into the hypotheca without reaching the antapex (Fig. 5). The $S_{s}$ plate is small and rhomboidal in shape and connected to the $T$-plate on the left side (Figs 2, 9). The $S_{d}$ plate is triangular and positioned beneath the $S_{\mathrm{a}}$ plate, touching the $7^{\prime \prime}, 6 \mathrm{C}$, $5^{\prime \prime \prime}$, and $S_{p}$ plates (Figs 5,6 ). The $S_{m}$ plate is almost completely hidden by the anterior part (wing) of the $S_{p}$ plate (Fig. 5) and can be seen when the $S_{d}$ plate is damaged (Fig. 9). The first cingulum plate (T-plate) is notched on the right margin where it meets the borders of the $S_{s}$ plates and also contacts the $S_{a}$ plate (Figs 9, 15).

Cells contain several peripherally placed brown-green chloroplasts that are round to oval in shape and irregularly arranged (Figs 13, 14). The spherical nucleus is prominent as a pale region positioned in the hypotheca (Fig. 14), and a large yellowish-orange accumulation body is visible in the epitheca near the apex of cultured cells (Figs 11-14). Laboratory cultured cells show positive growth at temperatures ranging from $17^{\circ} \mathrm{C}$ to $27^{\circ} \mathrm{C}$. Resting cysts were produced when cultures were grown in nitrate- and phosphate-deficient media; however, cyst concentrations were usually low and were not significantly altered over the $17-27^{\circ} \mathrm{C}$ temperature range investigated here. No encystment was noted in nutrient-replete cultures.

Cultured resting cysts are covered with numerous, narrow, slightly tapered nontabular calcareous spines. A clear thin outer membrane is often evident surrounding the spines produced in culture (Figs 17, 19). Similar calcareous cysts were also isolated from the sediment samples (Figs 16, 18). However, both $S$. irregularis cultures were germinated from a clear-walled, spineless cyst. Cultured cysts are spherical to oval in shape and grey-brown in colour with a prominent red-orange accumulation body. Cyst body diameter ranges from 20 to $26 \mu \mathrm{m}(\bar{X}=24 \mu \mathrm{m}, n=15)$ in diameter, with the process length ranging from 3.5 to $4.5 \mu \mathrm{m}$ (average $=4 \mu \mathrm{m}, n=15$ ). Cultured cysts have both capitate and pointed spines, whereas wild cysts appeared to have only pointed spines. No clearly defined archeopyle was observed in germinated specimens.

\section{Phylogenetic analyses}

Significant negative skewness of the random tree distribution was observed in both the $\mathrm{NJ}$ analysis including 56 taxa $(\mathrm{gl}=-0.511, P<0.01)$ and the MP analysis including 27 taxa ( $\mathrm{g} 1=-0.915, P<0.01)$, indicating that the data sets were phylogenetically informative. Both analyses produced trees with similar branching of major clusters; therefore, only the MP analysis with 27 taxa is shown (Fig. 20). The Calciodinelloidean taxa formed two major clades: the Ensiculifera Balech species and Pentapharsodinium dalei
Indelicate \& Loeblich form a well-supported cluster $(92 \%$ bootstrap support); the remaining Scrippsiella-like species (SCR clade) form a second major cluster with moderate (74\%) boostrap support. Scrippsiella hangoei Schiller consistently occupied a basal position among the Scrippsiella species in the analyses. The SCR clade includes members of the genera Scrippsiella, Calciodinellum Deflandre, Calcigonellum Deflandre, and Pernambugia Janofske \& Karwath. Within the SCR clade, three clusters are evident, referred to here as SCR.A, SCR.B, and SCR.C (Fig. 20). Both strains of $S$. irregularis cluster with Scrippsiella precaria and $S$. ramonii with $100 \%$ bootstrap support (SCR.A). The new species $S$. irregularis is most closely related to $S$. precaria (15.5\% sequence divergence) and then $S$. ramonii (17\% sequence divergence). The second cluster (SCR.B) includes the Scrippsiella trochoidea complex, Calciodinellum levantinum Meier, Janofske \& Willems, and Scrippsiella trifida Lewis. The third cluster (SRC.C) includes Calciodinellum albatrosianum, C. operosum, Calciodinellum sp., with Scrippsiella infula and Scrippsiella rotunda forming a related sister group to the Calciodinellum species. Three species, S. sweeneyae (Balech) Loeblich, S. lachrymosa Lewis, and Pernambugia tuberosa Kamptner \& Janofske, are not clearly allied with any of the three clusters.

\section{DISCUSSION}

The primary taxonomic feature for separating Scrippsiella species is the arrangement and shape of the thecal plates (Fensome et al. 1993; D'Onofrio et al. 1999; Montresor et al. 1997; Janofske 2000). The typical plate pattern in the genus is Po, $\mathrm{X}, 4^{\prime}, 3 \mathrm{a}, 7^{\prime \prime}, 6 \mathrm{C}\left(5 \mathrm{C}+1 \mathrm{~T}\right.$-plate), 5S, $5^{\prime \prime \prime}$ and $2^{\prime \prime \prime \prime}$. In most species the anterior intercalary plates are symmetrically arranged, with pentagonal $1 \mathrm{a}$ and $3 \mathrm{a}$ plates separated by a hexagonal $2 \mathrm{a}$ plate. However, plate tabulation within the genus is highly conserved; therefore, cell shape and outline and the shape of various thecal plates are considered important features separating species (Montresor et al. 2003).

The anterior dorsal plate pattern of $S$. irregularis differs from the more typical symmetrical arrangement. The la and $3 \mathrm{a}$ plates are asymmetrically arranged and in direct contact with each other, and the $2 \mathrm{a}$ plate contacts both the la and 3a plates on the posterior margin. This asymmetrical arrangement of the dorsal epithecal plates is known as cinctioid tabulation (Fensome et al. 1993) and matches the cinctioid tabulation (sensu Fensome et al. 1993) of both $S$. precaria (Montresor \& Zingone 1988) and S. ramonii (Montresor 1995).

The general cell morphology and tabulation of $S$. irregularis is more similar to $S$. precaria than $S$. ramonii, the latter readily distinguished by a prominent antapical horn on the $2^{\prime \prime \prime}$ plate (Montresor 1995). The cell shape of $S$. irregularis is more rounded than $S$. precaria (Fig. 21), but its dome-shaped epitheca is more similar to that of $S$. ramonii. Despite the similarities in plate patterns of all three cinctioid Scrippsiella species, the shape and relative size of some plates and cytological features are sufficiently different to distinguish $S$. irregularis. Firstly, the subrectan- 


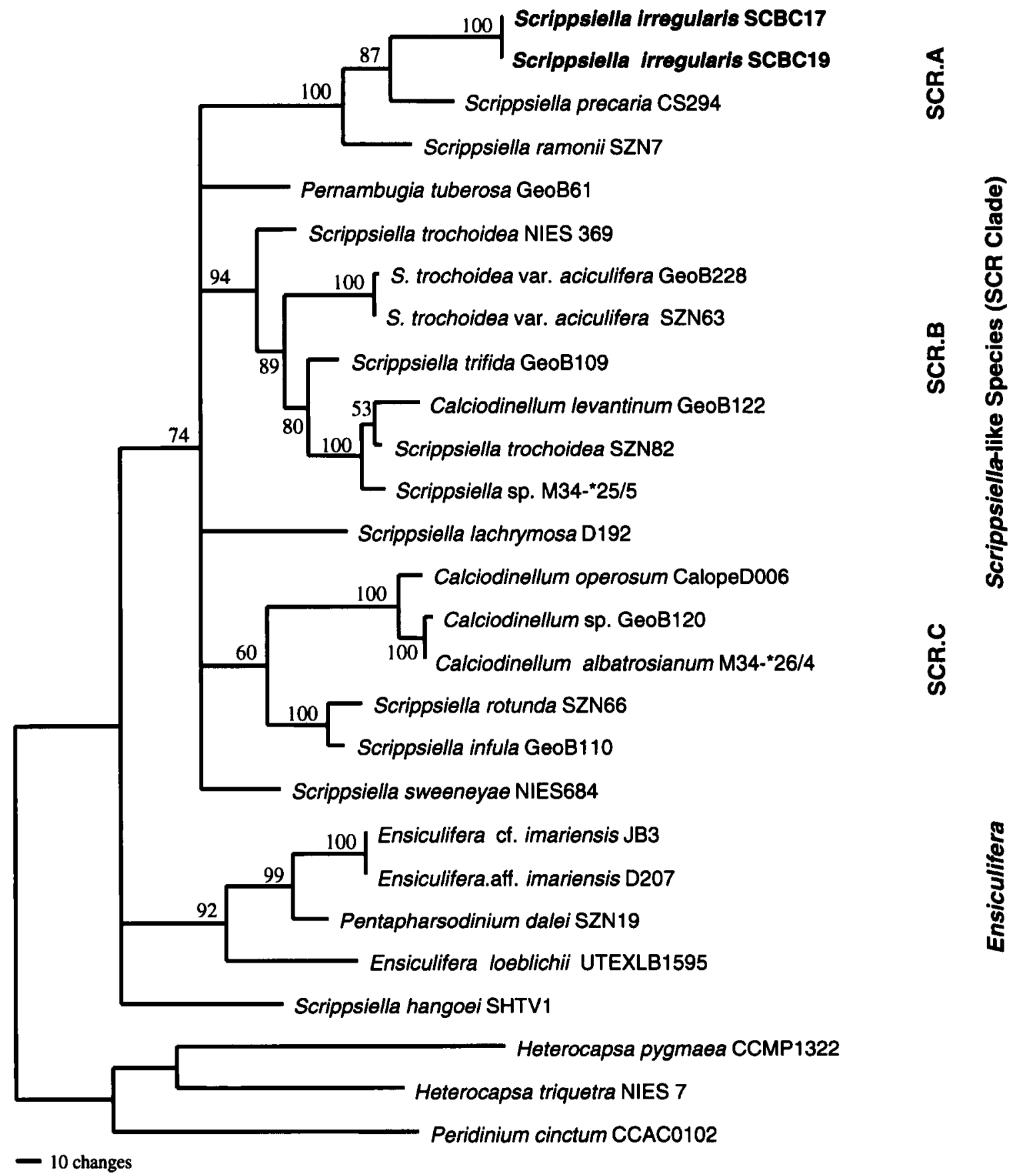

Fig. 20. Phylogeny of 27 taxa of Calciodinellaceae inferred from 5.8s and both ITS1 and ITS2 of rRNA region. A bootstrap consensus tree obtained by parsimony analysis from 100 replicates using the branch and bound search option of PAUP 4.0*. Bootstrap support for each cluster is indicated; branches with $<50 \%$ support are collapsed to polytomies. Heterocapsa triquetra, H. pygmaea, and Peridinium cinctum were used as outgroup taxa. Species from the present study are indicated in bold. The three subclades SCR.A, SCR.B, and SCR.C within the genus Scrippsiella (Gottschling et al. 2005) and the genus Ensiculifera are indicated by the shaded boxes.

gular 2 a plate of $S$. irregularis is much larger than the small diamond-shaped 2 a plate of $S$. precaria and more similar to the 2a plate of $S$. ramonii, which possesses two curved sides. Secondly, the narrower cingulum of $S$. irregularis is also clearly more equatorially placed than the cingulum of $S$. precaria (Fig. 21). Thirdly, the shape and conformation of the sulcal plates of $S$. irregularis differ from $S$. precaria. The transitional plate of $S$. irregularis terminates at the junction of the $1^{\prime}$ and $1^{\prime \prime}$ plates, and the first apical plate as in $S$. precaria (compare fig. la from Montresor \& Zingone 1988) extends apically to border the 1' plate, although it is possible that this connection may vary within $S$. precaria. Finally, the nucleus is located in the hypotheca, whereas the nucleus of $S$. precaria is in the anterior part of the cell, almost entirely above the equatorial plane (Montresor \& Zingone 1988).

The cysts of $S$. precaria and $S$. irregularis are very similar. Both are spherical to subspherical and covered with 

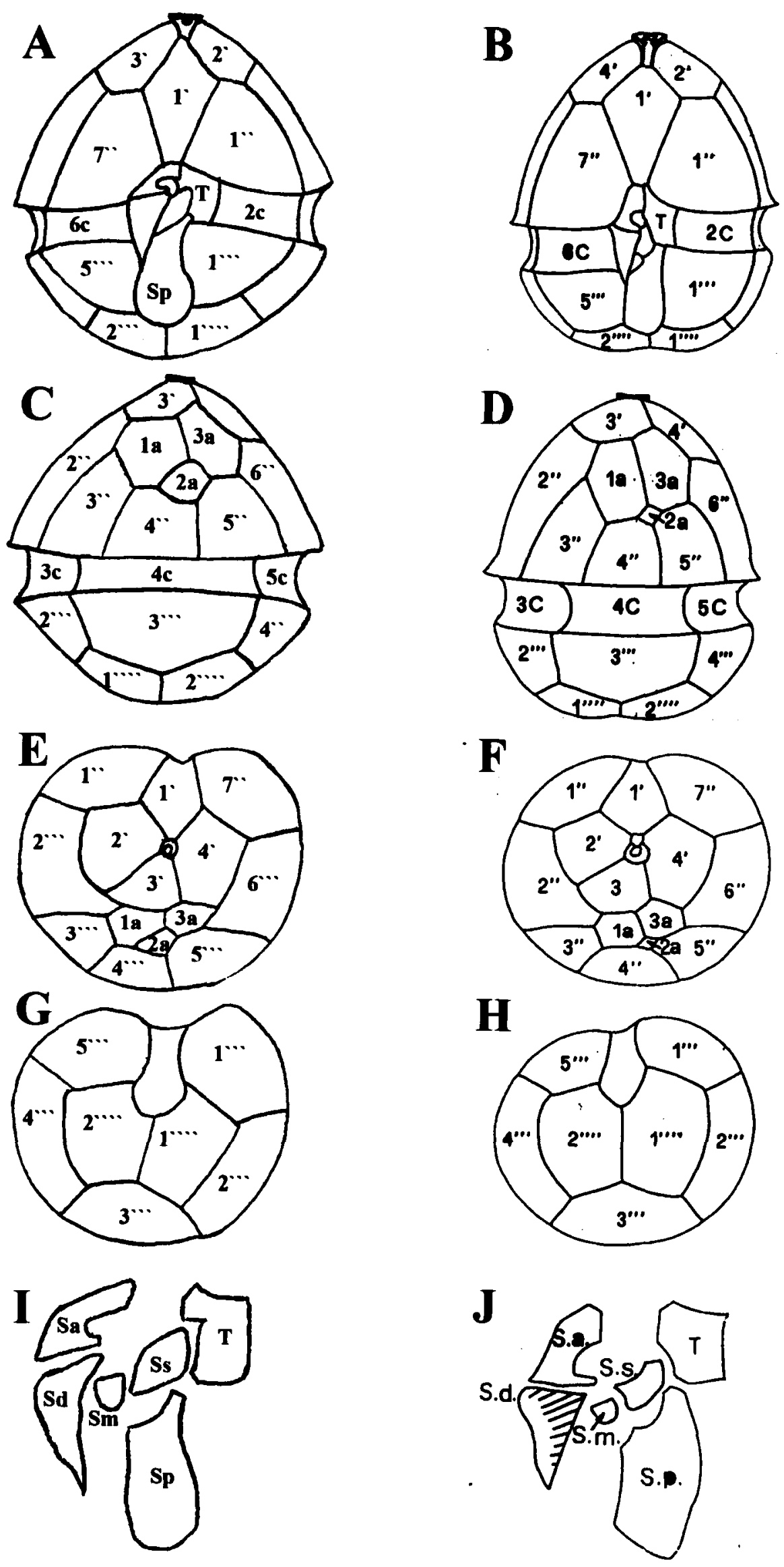
Table 2. Morphological comparison of motile cells and resting cysts of Scrippsiella irregularis sp. nov., Scrippsiella precaria (Montresor \& Zingone 1988), and Scrippsiella ramonii (Montresor 1995).

\begin{tabular}{|c|c|c|c|}
\hline Feature & S. ramonii & S. precaria & S. irregularis \\
\hline \multicolumn{4}{|l|}{ Motile cells } \\
\hline Length $(\mu \mathrm{m})$ & $22-34$ & $15-25(\bar{X}=19.2)$ & $17-29(X=22)$ \\
\hline Width $(\mu \mathrm{m})$ & $19-27$ & $13.8-20(\bar{X}=16)$ & $13-23(\bar{X}=18)$ \\
\hline Cingulum width $(\mu \mathrm{m})$ & ? & $(\bar{X}=4.1)$ & $2.6-3.6(\bar{X}=2.9)$ \\
\hline Cingulum displacement & $?$ & $2 / 3$ of its width & $1 / 2-1$ of its width \\
\hline Cell apex & rounded & rounded & rounded \\
\hline Cell antapex & small horn & flattened & rounded \\
\hline Epitheca/hypotheca ratio & ? longer & 1.6 & 1.4 \\
\hline 2a plate; size shape & large & small & medium \\
\hline Nucleus; shape & $\begin{array}{l}\text { rhombic } \\
\text { spherical }\end{array}$ & $\begin{array}{l}\text { rhomboidal } \\
\text { spherical }\end{array}$ & rounded subrectangular \\
\hline Position & central & anterior & posterior \\
\hline Colour & yellow-green & olive-green & brown-green \\
\hline \multicolumn{4}{|l|}{ Resting cysts } \\
\hline Size $(\mu \mathrm{m})$ & $\begin{array}{l}31-36 \text { long } \\
25-26 \text { wide }\end{array}$ & $\begin{array}{l}17.5-25(\bar{X}=20.5) ; 15-23 \\
\quad(\bar{X}=18.6)\end{array}$ & $20-26(\bar{X}=24)$ \\
\hline Cyst shape & ovoid & spherical to oval & spherical to subspherical \\
\hline Colour & dark brown & light brown & light brown-grey \\
\hline Process termination & capitate & $\begin{array}{l}\text { generally pointed, sometimes } \\
\text { capitate }\end{array}$ & pointed and capitate spines \\
\hline Process length $(\mu \mathrm{m})$ & $9-11.5$ & $3.1-6.9(\bar{X}=4.7)$ & $3.6-4.5(X=4)$ \\
\hline
\end{tabular}

nontabular calcareous spines; however, $S$. irregularis cysts are slightly larger with slightly shorter spines (Table 1). Cysts of $S$. ramonii are somewhat more easily distinguished by their oval shape, dark brown colour, and significantly longer calcareous processes (Montresor 1995).

The phylogenetic analysis presented here identifies three main clusters within Scrippsiella that have been identified by previous studies (D'Onofrio et al. 1999; Montresor et al. 2003; Gottschling et al. 2005). While each cluster is composed of morphologically similar strains, there is no clear link between the clustering and cell or cyst morphology of the species within each cluster. The exception is the cluster of species (SCR.A) that includes $S$. precaria, $S$. ramonii, and $S$. irregularis sp. nov. All three possess the distinctive asymmetrical arrangement of intercalary plates (Montresor \& Zingone 1988; Montresor 1995) and have a wide rhomboidal first apical plate. Asymmetrically arranged anterior intercalary plates are also a feature of $S$. hangoei Schiller, yet our phylogenetic analyses indicate that $S$. hangoei is distinct from the SCR.A cluster and other Scrippsiella species. In this species, plates $1 \mathrm{a}$ and $2 \mathrm{a}$ are irregularly pentagonal rather than hexagonal, and plate $3 a$ is much larger and hexagonal rather than rhomboidal. Resting cysts of $S$. hangoei differ from other Scrippsiella species by having an organic wall bearing furcate organic processes rather than calcareous spines (Larsen et al. 1995). Cultured resting cysts are spherical and smooth-walled and lack furcate processes (Kremp et al. 2005). Three benthic Scrippsiella-like species recently transferred to the genus Bysmatrum Faust \& Steidinger also show asymmetrical anterior intercalary tabulation, but, in this genus, plates $2 \mathrm{a}$ and $3 \mathrm{a}$ are separated by the $3^{\prime}$ plate, and the thecal plates have a reticulated surface (Faust \& Steidinger 1998). All other Scrippsiella species generally exhibit a symmetrical anterior intercalary plate arrangement composed of a hexagonal $2 a$ plate inserted between pentagonal $1 a$ and $3 a$ plates.

The highly supported clustering of $S$. irregularis sp. nov. with $S$. precaria and $S$. ramonii in our phylogenetic analyses (SCR.A) strongly supports our placement of the new species within Scrippsiella as part of the group possessing cinctioid epithecal tabulation. While $S$. irregularis is morphologically similar to $S$. precaria, the sequence divergence between these two species is greater than that between $S$. precaria and $S$. ramonii. Combined with the morphological differences, our data clearly support our recognition of $S$. irregularis as a new species distinct from $S$. precaria and $S$. ramonii.

\section{ACKNOWLEDGEMENTS}

The authors thank Sharareh Khodami from the Iranian Fisheries Research Institute (IFRI) for sediment collection and arranging sample transport to Australia. We also thank Geraldine Nash (Antarctic Division, Hobart, Australia), Dr Tae-Gyu Park (School of Plant Science, University of Tasmania, Hobart, Australia), and David Steele (Central Science Laboratory, University of Tasmania, Hobart, Australia) for assistance with SEM preparation and imaging. 


\section{REFERENCES}

AdachI M., Sako Y. \& IshidA Y. 1994. Restriction fragment length polymorphism of ribosomal DNA internal transcribed spacer and $5.8 \mathrm{~s}-$ regions in Japanese Alexandrium species (Dinophyceae). Journal of Phycology 30: 857-863.

BlackburN S.I., HallegraefF G.M. \& BolCh C.J. 1989. Vegetative reproduction and sexual life-cycle of the toxic dinoflagellate Gymnodinium catenatum from Tasmania, Australia. Journal of Phycology 25: 577-590.

BolCH C.J.S. 1997. The use of sodium polytungstate for the separation and concentration of living dinoflagellate cysts from marine sediments. Phycologia 36: 472-478.

BolCh C.J. \& HallegraefF G.M. 1990. Dinoflagellate cysts in recent marine sediments from Tasmania, Australia. Botanica Marina 33: 173-192.

BolCh C.J., BLACKBURN S.I., HallegraefF G.M. \& VallLanCourT R.E. 1998. Genetic variation among different global populations of Gymnodinium catenatum revealed by RAPD-PCR. In: Harmful microalgae (Ed. B. Reguera, J. Blanco, M.L. Fernandez \& T. Wyatt), pp. 283-286. Xunta de Galicia and UNESCO, Paris.

DALE B. 1992. Dinoflagellate contributions to the open ocean sediment flux. In: Dinoflagellate contributions to the deep sea (Ed. B Dale \& A.L. Dale), pp. 1-31. Woods Hole Oceanographic Institution Ocean Biocoenosis Series, Woods Hole, Massachusetts.

D'Onofrio G., Marino D., Bianco L., Busico E. \& Montresor M. 1999. Toward an assessment on the taxonomy of dinoflagellates that produce calcareous cysts (Calciodinelloideae, Dinophyceae): a morphological and molecular approach. Journal of Phycology 35: 1063-1078.

FAUST M.A. 1996. Morphology and ecology of the marine benthic dinoflagellate Scrippsiella subsalsa (Dinophyceae). Journal of Phycology 32: 669-675.

FAust M.A. \& Steidinger K.A. 1998. Bysmatrum gen. nov. (Dinophyceae) and three new combinations for benthic scrippsielloid species. Phycologia 37: 47-52.

FELSENSTEIN J. 1985. Confidence limits on phylogenies: an approach using the bootstrap. Evolution 39: 783-791.

FENSOME R.A., TAylor F.J.R., Norris G., SARgEANT W.A.S., Wharton D.I. \& Williams L.G. 1993. Classification of living and fossil dinoflagellates American Museum of Natural History, New York, $351 \mathrm{pp}$.

FrITZ L. \& TREIMER R.E. 1985. A rapid simple technique utilizing calcofluor white M2R for the visualization of dinoflagellate thecal plates. Journal of Phycology 21: 662-664.

Godhe A., Karunasagar I. \& KarLSON B. 2000. Dinoflagellate cysts in recent marine sediments from SW India. Botanica Marina 43: 39-48.

Gottschling M., KNop R., Plotner J., Kirsch M., Willems H. \& KEUPP H. 2005. A molecular phylogeny of Scrippsiella sensu lato (Calciodinellaceae, Dinophyta) with interpretations on morphology and distribution. European Journal of Phycology 40: 207-220.

HALL T.A. 1999. BioEdit: a user-friendly biological sequence alignment editor and analysis program for Windows 95/98/NT. Nucleic Acids Research, Symposium Series 41: 95-98.
Hillis D.M. \& Huelsenbeck J.P. 1992. Signal, noise, and reliability in molecular phylogenetic analyses. Journal of Heredity 83: $189-195$.

Honsell G. \& Cabrini M. 1991. Scrippsiella spinifera sp. nov. (Pyrrhophyta): a new dinoflagellate from the northern Adriatic Sea. Botanica Marina 34: 167-175.

JANOFSKE D. 2000. Scrippsiella trochoidea and Scrippsiella regalis, nov. comb. (Peridiniales Dinophyceae): a comparison. Journal of Phycology 36: 178-189.

Jeanmougin F., Thompson J.D., Gouy M., Higgins D.G. \& GiBson T.J. 1998. Multiple sequence alignment with Clustal X. Trends in Biochemical Sciences 23: 403-500.

Kobayashi S. \& Matsuoka K. 1995. A new species of Ensiculifera, E. imariense (Dinophyceae), producing organicwalled cysts. Journal of Phycology 31: 147-152.

Kremp A., Elbrächter M., SCHWEIKeRT M., Wolny J.L. \& GotTsCHLING M. 2005. Woloszynskia halophyla (Biecheler) comb. nov.: a bloom-forming cold-water dinoflagellate cooccurring with Scrippsiella hangoei (Dinophyceae) in the Baltic Sea. Journal of Phycology 41: 629-643.

larsen J., Kuosa H., Ikavalko J., Kivi K. \& Hallfors S. 1995. A redescription of Scrippsiella hangoei (Schiller) comb. nov., a red tide dinoflagellate from the northern Baltic. Phycologia 34: 135-144.

Marchant H. \& Thomas D. 1983. Polylysine as an adhesive for the attachment of nanoplankton to substrates for electron microscopy. Journal of Microscopy 131(1): 127-129.

MONTRESOR M. 1995. Scrippsiella ramonii sp. nov. (Peridiniales, Dinophyceae), a marine dinoflagellate producing a calcareous resting cyst. Phycologia 34: 87-91.

MONTRESOR M. \& ZiNGONE A. 1988. Scrippsiella precaria sp. nov. (Dinophyceae), a marine dinoflagellate from the Gulf of Naples. Phycologia 27: 387-394.

MONTRESOR M., JANOFSKe D. \& Willems H. 1997. The cyst-theca relationship in Calciodinellum operosum emend. (Peridiniales, Dinophyceae) and a new approach for the study of calcareous cysts. Journal of Phycology 33: 122-131.

Montresor M., Sgrosso S., Procaccini G. \& Kooistra W. 2003. Intraspecific diversity in Scrippsiella trochoidea (Dinophyceae): evidence for cryptic species. Phycologia 42: 56-70.

NATION J.L. 1983. A new method using hexamethyldisilazane for preparation of soft insect tissues for scanning electron microscopy. Stain Technology 58: 347-351.

SwOFFORD D.L. 2002. PAUP*: phylogenetic analysis using parsimony and other methods. Version 4. Sinauer Associates, Sunderland, Massachusetts.

Vink A. 2004. Calcareous dinoflagellate cysts in south and equatorial Atlantic surface sediments: diversity, distribution, ecology and potential for palaeoenvironmental reconstruction. Marine Micropaleontology 50: 43-88.

Received 2 January 2007; accepted 14 May 2007 Associate editor: Stuart Sym 